human reproduction

\title{
Fertile offspring derived from mouse spermatogonial stem cells cryopreserved for more than 14 years
}

\author{
Xin Wu', Shaun M. Goodyear', Lara K. Abramowitz ${ }^{2}$, \\ Marisa S. Bartolomei ${ }^{2}$, John W. Tobias ${ }^{3}$, Mary R. Avarbock', \\ and Ralph L. Brinster ${ }^{1, *}$
}

\author{
'Department of Animal Biology, School of Veterinary Medicine, University of Pennsylvania, 3850 Baltimore Avenue, Philadelphia, PA 19I04, \\ USA ${ }^{2}$ Department of Cell and Developmental Biology, School of Medicine, University of Pennsylvania, Philadelphia, PA 19104, USA \\ ${ }^{3}$ Penn Bioinformatics Core, University of Pennsylvania, Philadelphia, PA 19104, USA \\ *Correspondence address. Tel: + I-215-898-8805; Fax: + I-215-898-0667; E-mail: cpope@vet.upenn.edu
}

Submitted on December 15, 2011; resubmitted on January 18, 2012; accepted on February 14, 2012

\begin{abstract}
BACKGROUND: Approximately $80 \%$ of childhood cancers can now be cured but a side effect of treatment results in about one-third of the surviving boys being infertile or severely subfertile when they reach reproductive age. Currently, more than I in 5000 men of reproductive age who are childhood cancer survivors suffer from this serious quality of life problem. It is possible to obtain a testicular biopsy before treatment to preserve the spermatogonial stem cells (SSCs) of the male by cryopreservation, but the results of long-term storage of SSCs on their subsequent functional ability to generate normal offspring has not been examined in any mammalian species. Moreover, it will be necessary to increase the number of these cryopreserved SSCs to remove any contaminating malignant cells and assure regeneration of spermatogenesis.
\end{abstract}

METHODS AND RESULTS: In this report, we demonstrate that long-term cryopreservation ( $>14$ years) of testis cells from mouse, rat, rabbit and baboon safeguards SSC viability, and that these cells can colonize the seminiferous tubules of recipient testes. Moreover, mouse and rat SSCs can be cultured and re-establish complete spermatogenesis, and fertile mouse progeny without apparent genetic or epigenetic errors were generated by the sperm produced.

CONCLUSIONS: These findings provide a platform for fertility preservation in prepubertal boys undergoing gonadotoxic treatments.

Key words: cryopreservation / germ cells / spermatogenesis / spermatogonial stem cells / male infertility

\section{Introduction}

Chemotherapy or radiation treatment can cause extensive gonadal damage, resulting in infertility, emphasizing the need for men and boys to safeguard their fertility prior to cancer treatment (Jahnukainen et al., 2006; Brinster, 2007; Mitchell et al., 2009; Sauvat et al., 2009; Schlatt et al., 2009; Wyns et al., 2010, 201।; Jahnukainen et al., 20lla,b). Adult males can produce sperm for cryopreservation, whereas prepubertal boys cannot. It is estimated that at least $I$ in 5000 males of reproductive age currently suffer from infertility or severely compromised fertility as a result of successful treatment of childhood cancer (Hewitt et al., 2003; Ginsberg et al., 20l0). Cryopreservation of testicular tissue from boys before treatment may allow for future transplantation of spermatogonial stem cells (SSCs) and re-establishment of fertility (Radford, 2000; Brinster,
2007; Geens et al., 2008; Ginsberg et al., 2010). However, it is unknown whether SSCs will survive cryopreservation for more than a few months, and the success of this approach is further complicated by the small tissue biopsy size; both of which may severely restrict the number of viable SSCs capable of re-establishing spermatogenesis (Geens et al., 2008; Wu et al., 2009). If SSCs indeed survive long-term cryopreservation, they would likely require in vitro expansion prior to transplantation, yet the effect of long-term storage and culture raise safety concerns regarding the unwanted genetic and epigenetic changes that can be transferred to the offspring (Radford, 2000; Alukal and Lipshultz, 2008; Wu et al., 2009).

Fifteen years ago, we reported that mouse SSCs could be cryopreserved for up to 5 months and re-establish spermatogenesis in the testes of infertile mice (Avarbock et al., 1996). Using a similar approach, progeny can be generated following 2-7 weeks of

(C) The Author 2012. Published by Oxford University Press on behalf of the European Society of Human Reproduction and Embryology. All rights reserved.

For Permissions, please email: journals.permissions@oup.com 
cryopreservation (Kanatsu-Shinohara et al., 2003). However, in those studies the storage period was short, and the availability of donor tissue was not restricted. We hypothesized that SSCs of most species can be cryopreserved for long periods and describe here the impact of long-term cryopreservation $(\sim 12-14$ years) on the viability and function of SSCs from mouse, rat, rabbit and baboon.

\section{Materials and Methods}

\section{Germ cell cryopreservation}

Donor testis cells were isolated and cryopreserved between 1995 and 1998 as previously described (Avarbock et al., 1996). In brief, testes from ZFLacZ mouse $(n=53$ mice), rat $(n=2)$, rabbit $(n=1)$ and baboon $(n=1)$ were enzymatically digested, and the donor testis cells resuspended in Dulbecco's modified Eagle's medium (DMEM) containing $10 \%$ fetal bovine serum (FBS), $2 \mathrm{mM}$ glutamine, $6 \mathrm{mM}$ lactate, $0.5 \mathrm{mM}$ pyruvate, 30 units $/ \mathrm{ml}$ penicillin and $50 \mu \mathrm{g} / \mathrm{ml}$ streptomycin (termed DMEM-c) at a concentration of $16-40 \times 10^{6}$ cells $/ \mathrm{ml}$. In drop-wise amounts, freezing medium comprising FBS, DMEM-c and dimethylsulfoxide (DMSO) (in a 1:3:1 ratio) was added to equal volumes of ZFLacZ mouse, rabbit and baboon testis cells (Avarbock et al., 1996). In contrast, ROSA mouse testes ( $n=4$ mice) were cut in half, placed in vials in I $\times$ phosphate-buffered saline (PBS), and 10\% DMSO added prior to freezing. Vials of cells for cryopreservation were first frozen at $-70^{\circ} \mathrm{C}$ and then placed in liquid $\mathrm{N}_{2}\left(-196^{\circ} \mathrm{C}\right)$.

To thaw cryopreserved testis cells or pieces of testes, samples were removed from liquid nitrogen and immediately placed in a $34^{\circ} \mathrm{C}$ water bath and processed as previously described (Avarbock et al., 1996; Oatley and Brinster, 2006; Kubota and Brinster, 2008). In brief, thawed cells were washed three times in I $\times$ Hank's balanced salt solution (HBSS) (Invitrogen, Carlsbad, CA, USA), with a brief 7 min centrifugation $\left(600 \mathrm{~g}, 4^{\circ} \mathrm{C}\right)$ between each wash step in order to remove residual DMSO. Cryopreserved testis pieces derived from adult ( $\sim 3$ months old) ROSA mice were thawed, the tunica was removed and then digested for $10 \mathrm{~min}$ at $37^{\circ} \mathrm{C}$ in $0.25 \%$ trypsin EDTA (Invitrogen) containing $7 \mathrm{mg} / \mathrm{ml}$ DNase I (Sigma, St. Louis, MO, USA). Digestion was inhibited by the addition of 10\% FBS (Invitrogen). Thawed testis cells for mouse, rat, rabbit and baboon were collected by centrifugation $\left(7 \mathrm{~min}, 600 \mathrm{~g}, 4^{\circ} \mathrm{C}\right)$ and resuspended in $\mathrm{HBSS}$ and then centrifuged $\left(7 \mathrm{~min}, 600 \mathrm{~g}, 4^{\circ} \mathrm{C}\right)$ twice through a sedimentation gradient comprising 30\% Percoll (Sigma). Cells were again washed three times in HBSS to remove residual Percoll. Dye exclusion using trypan blue was used to determine the number of viable cells present in the cell suspension following thawing and after centrifugations in Percoll. This process resulted in a testis cell population with viability greater than $93 \%$ (Table I). For mouse studies, testis cell suspensions were derived from either prepubertal (age 6-14 days) ZFlacZ pups or adult ( $\sim 3$ months old) ROSA mice. All testis cells were resuspended in mouse serum-free medium (mSFM) containing human glial cell-derived neurotrophic factor (GDNF) $(20 \mathrm{ng} / \mathrm{ml}$; R\&D Systems, Minneapolis, MN, USA), rat GDNF family receptor $\alpha \mid$ (GFR $\alpha$ I)-Fc fusion protein (I50 ng/ml; R\&D Systems) and human basic fibroblast growth factor (bFGF) (I ng/ml; BD Biosciences, San Diego, CA, USA) (Oatley and Brinster, 2006; Kubota and Brinster, 2008). Both mouse strains contain the transgene $\beta$-galactocidase (LacZ); however, ROSA mice $\beta$-gal expression is constitutive (Nagano et al., 1999), whereas in ZFLacZ mice, $\beta$-gal expression is under the control of the zinc-finger gene on the $Y$ chromosome (ZPY) promoter and expressed first in round spermatids (Zambrowicz et al., 1994). Cryopreserved rat testis cells were derived from prepubertal ( $\sim$ I month) MTLacZ rats carrying the LacZ transgene under the control of the mouse metallothionein I (MT) promoter. The
LacZ transgene is first expressed in spermatocytes in MTLacZ donor rats (Clouthier et al., 1996).

\section{Testis cell transplantation}

Recipient mice for transplantation were prepared as previously described (Brinster and Avarbock, 1994; Brinster and Zimmermann, 1994). In brief, adult mice were treated with the alkylating agent busulfan $(50-60 \mathrm{mg} / \mathrm{kg}$; Sigma), at least 6 weeks prior to transplantation of donor cells. For donor testis cells derived from ROSA or ZFLacZ mice, immunocompatable 129/ SvCP $\times$ C57BL/ 6 or SJL $\times$ C57BL/6 F, hybrid mice, respectively, were used as recipients (Brinster and Avarbock, 1994; Nagano et al., 1999). Immunodeficient Ncr Swiss nude mice (Taconic, Hudson, NY, USA) were used as recipients for transplantation of rabbit, baboon or MTLacZ rat testis cells. For transplantation into recipients, donor mouse testis cells were resuspended in mSFM at a concentration of $1 \times$ $10^{7}$ cells $/ \mathrm{ml}$ (ZFLacZ) and I $\times 10^{6}$ cells $/ \mathrm{ml}$ (ROSA), and $10 \mu \mathrm{l}$ of the donor testis cell suspension was microinjected into each recipient testis via the efferent duct, as previously described (Oatley and Brinster, 2006 Kubota and Brinster, 2008). Donor testis cells from rabbit, baboon or MTLacZ rats were resuspended in rat serum-free medium (rSFM) (Oatley and Brinster, 2006; Kubota and Brinster, 2008) at a concentration ranging from 3 to $5 \times 10^{7}$ cells $/ \mathrm{ml}$, and $10 \mu \mathrm{l}$ of the donor testis cell suspension was microinjected into each testis of a busulfan-treated $(50 \mathrm{mg} / \mathrm{kg})$ immunodeficient Ncr Swiss nude recipient mouse (Taconic) (Dobrinski et al., 1999; Nagano et al., 200I). Testis cells derived from either rabbit or baboon were each transplanted into five $\mathrm{Ncr}$ Swiss nude recipient mice. At the time of transplantation testis cell viability was $\geq 93 \%$ (Table I).

To compare differences in spermatogenesis between cryopreserved SSCs and freshly isolated SSCs, busulfan-treated recipient mouse testes were transplanted with freshly isolated or cryopreserved $(\sim 12$ years) donor testis cells derived from ROSA mice (Table I). Two months after transplantation, the transplanted testes were removed and stained with 5-bromo-4-chloro-3-indolyl b-D-galactoside (X-gal). Colony number and colony length were determined using a dissecting microscope (Leica Microsystems, Bannockburn, IL, USA) and a Scale Master Classic (Scale Master Tech., NV, USA) measuring instrument (Fig. ID). To further evaluate spermatogenesis, recipient mice were also transplanted with cryopreserved ( $\sim 4$ years) ZFLacZ testis cells (Table I). Three to 6 months after transplantation, the testes were stained with $X$-gal and the seminiferous tubules examined for positive $\mathrm{X}$-gal staining, representing colonies of spermatogenesis. Histological sections of representative colonies in testes, stained with $\mathrm{X}$-gal, were also prepared.

The impact of long-term cryopreservation on rabbit and baboon SSCs was also assessed using functional transplantation assays. Prior to transplantation into mice, rabbit testis cells were labeled with the fluorescent dye PKH26 (Sigma) according to the manufacturer's directions. At I week and 2 months after transplantation, the recipient testes were removed and examined for clusters of red fluorescent cells. Specifically, tubules from these recipient testes were tweezed apart and clusters of red fluorescent cells were observed using a Nikon Eclipse T5100 microscope fitted with a Nikon Coolpix 4500 digital camera. Cryopreserved baboon testes cells transplanted into recipient testes were also assessed I week and 2 months after transplantation. The testes of recipient mice transplanted with baboon testis cells were removed, the tubules tweezed apart and immunostained for the expression of UCHLI (PGP9.5; AbD Serotec, Raleigh, NC, clone \#7863-0504), a protein previously shown to be expressed in spermatogonia of multiple species (Luo et al., 2009). The detection of primary antibody was carried out using a commercial horse-radish peroxidase detection kit (Histostain-SP; Invitrogen). Baboon germ cells contained within recipient tubules were visualized under bright field using the same microscope described above. All animal 
Table I Testis cells stored at $-196^{\circ} \mathrm{C}$ for $\sim 1 \mathrm{I}-14$ years.

\begin{tabular}{|c|c|c|c|c|c|c|c|c|}
\hline Species & $\begin{array}{l}\text { Genetic } \\
\text { background }^{a}\end{array}$ & $\begin{array}{l}\text { Date } \\
\text { frozen }\end{array}$ & $\begin{array}{l}\text { Age at } \\
\text { freezing }\end{array}$ & $\begin{array}{l}\text { Date } \\
\text { thawed }\end{array}$ & $\begin{array}{l}\text { Period frozen } \\
\text { (year/month) }\end{array}$ & $\begin{array}{l}\text { Freezing } \\
\text { medium }^{\mathrm{a}}\end{array}$ & $\begin{array}{l}\text { Post-thaw } \\
\text { viability of } \\
\text { testis cells }\end{array}$ & $\begin{array}{l}\text { Viability of } \\
\text { testis cells } \\
\text { after } \\
\text { percollc }^{(\%)}\end{array}$ \\
\hline $\begin{array}{l}\text { Mouse (Mus } \\
\text { musculus) }\end{array}$ & ZFlacZ transgenic & $\begin{array}{l}20 \mathrm{Nov} \\
1995\end{array}$ & $6-14$ day & 6 Jan 2010 & 14 year/1.6 month & $\begin{array}{l}\text { DMEM + 15\% } \\
\text { FBS + 10\% DMSO }\end{array}$ & $12.3-17.0 \%$ & 93 \\
\hline $\begin{array}{l}\text { Mouse (Mus } \\
\text { musculus) }\end{array}$ & $\begin{array}{l}\text { Rosa lacZ } \\
\text { transgenic }\end{array}$ & 4 Jan 1998 & $\sim 3$ month & $\begin{array}{l}\text { II Dec } \\
2009\end{array}$ & II year/8.4 month & $\mathrm{PBS}+10 \% \mathrm{DMSO}^{\mathrm{b}}$ & $2.8-3.6 \%$ & 99 \\
\hline $\begin{array}{l}\text { Rat (Rattus } \\
\text { norvegicus) }\end{array}$ & MT lacZ transgenic & 3 Jan 1996 & $\sim$ I month & 11 Jan 2010 & 13 year/ 10.4 month & $\begin{array}{l}\text { DMEM + } 15 \% \\
\text { FBS }+10 \% \text { DMSO }\end{array}$ & $1.5-2.3 \%$ & 93 \\
\hline $\begin{array}{l}\text { Rabbit (Oryctolagus } \\
\text { cuniculus) }\end{array}$ & NZW & $\begin{array}{l}10 \text { Jan } \\
1998\end{array}$ & $\sim 4$ month & 25 Jan 2010 & 12 year $/ 0.5$ month & $\begin{array}{l}\text { DMEM + 15\% } \\
\text { FBS + 10\% DMSO }\end{array}$ & $13 \%$ & 94 \\
\hline $\begin{array}{l}\text { Baboon (Papio } \\
\text { Anubis) }\end{array}$ & - & $\begin{array}{l}6 \mathrm{Nov} \\
1997\end{array}$ & 7 year & I Feb 2010 & 12 year $/ 2.9$ month & $\begin{array}{l}\text { DMEM + 15\% } \\
\text { FBS + 10\% DMSO }\end{array}$ & $13 \%$ & 95 \\
\hline
\end{tabular}

DMEM, Dulbecco's Modified Eagle's Medium; FBS, fetal bovine serum; DMSO, dimethylsulfoxide; PBS, phosphate-buffered saline.

a'Details in 'Materials and Methods' section.

bHalf pieces of whole testis were cryopreserved in freezing medium. Following thawing, tissue pieces were digested to obtain a cell suspension as described in Materials and Methods.

'Percentage of frozen testis cells recovered following several wash steps, including centrifugation through two separate Percoll density gradients (see 'Materials and Methods' section):

ZFlacZ transgenic $=9.8 \%$; ROSA lacZ transgenic $=1.1 \%$; Rat $=4.25 \% ;$ Rabbit $=14.8 \%$ and Baboon $=12.4 \%$.

experimentation protocols were approved by the Institutional Animal Care and Use Committee of the University of Pennsylvania.

\section{Intracytoplasmic sperm injection}

The testes of busulfan-treated SJL $\times$ C57BL/ 6 recipient mice transplanted with total testis cells derived from ZFLacZ mice were isolated 3-6 months after transplantation (four testes from two recipient mice were used for each microinsemination experiment; mouse \#A6090 and A609I). The testes were harvested, the tunica removed and the tissue washed twice with I $\times$ HBSS. Testes were incubated with $\mathrm{X}$-gal solution, without any fixation, for 30-60 min, until positive, light-blue staining revealed colonies of spermatogenesis generated from ZFLacZ stem cells. The testes were rapidly washed three times in $1 \times$ HBSS and the stained seminiferous tubules were carefully dissected and pooled. The tubules were digested in $0.25 \%$ trypsin EDTA (Sigma) containing $1 \mathrm{mg} / \mathrm{ml}$ collagenase IV (Sigma) for 15 min with occasional pipetting to disperse cells. Digestion was inhibited by 10\% FBS and the cell suspension was filtered through a $40 \mu \mathrm{m}$ cell strainer; cells were then washed twice by centrifugation (7 min, 600g, $4^{\circ} \mathrm{C}$ ) using $1 \times$ HBSS. The cell pellet was suspended in nuclear isolation medium (NIM) containing $6 \%$ polyvinyl alcohol (PVA) and sonicated (power-setting $=2$; Heat Systems-Ultrasonic, model \#W-220F) for $10 \mathrm{~s}$ to remove the sperm tails (Kimura and Yanagimachi, 1995). Cells were placed in drops of NIM on a dish containing mineral oil, and individual sperm heads were collected by micromanipulation under the microscope. The donor-derived sperm heads were microinjected into oocytes derived from dilute brown non-agouti $(D B A) \times$ C57BL/6 $F_{\text {I }}$ mice using a piezoelectric actuator (PrimeTech, Ibaraki, Japan). Injected oocytes were cultured overnight in Brinster's medium at $37^{\circ} \mathrm{C}$ in a humidified atmosphere of $5 \% \mathrm{O}_{2}, 5 \% \mathrm{CO}_{2}$ and $90 \% \mathrm{~N}_{2}$, before being transferred to the oviducts of Day I pseudo-pregnant ICR Swiss female mice, as previously reported (Brinster, 1965; Kimura and Yanagimachi, 1995).

\section{Cell culture}

In vitro culture of mouse and rat SSCs was carried out, as previously described (Oatley and Brinster, 2006; Kubota and Brinster, 2008). Following thawing and enrichment of viable cells through a Percoll sedimentation gradient as described above, the SSCs contained within cryopreserved mouse testis cells were enriched using Thy-I Antibody-Conjugated Magnetic Microbeads (MACS; Cat\#I30-042-20I, Miltenyi Biotec, Auburn, CA, USA). The SSC-enriched germ cell population was maintained on mitotically inactivated SIM mouse embryo-derived thioguanine-oubain resistant (STO) cell feeders in mSFM containing human GDNF $(20 \mathrm{ng} / \mathrm{ml})$, rat GFR $\alpha \mathrm{I}-\mathrm{Fc}$ fusion protein $(150 \mathrm{ng} / \mathrm{ml})$ and human bFGF (I ng/ml). SSC-enriched germ cell cultures established from cryopreserved $(\sim 14$ years) rat testis cells were maintained on mitotically inactivated STO feeder cells in rSFM, as previously described (Oatley and Brinster, 2006). All cultures were maintained at $37^{\circ} \mathrm{C}, 5 \% \mathrm{CO}_{2}$ in air (Oatley and Brinster, 2006; Kubota and Brinster, 2008).

\section{DNA isolation}

A small piece of mouse liver was used to isolate genomic DNA. Tissue was incubated with proteinase $K$ overnight and then DNA was isolated using the Qiagen DNeasy Blood \& Tissue Kit (Qiagen, Valencia, CA, USA).

\section{Array-based comparative genomic hybridization}

To evaluate the possible deleterious effects prolonged cryopreservation and assisted reproduction technologies (ARTs) may have on the DNA of $F_{0}$ progeny, we used array-based comparative genomic hybridization $(\mathrm{CGH})$ for analysis of genomic DNA. ICSI-derived progeny were generated from $0^{7}$ (ZFLacZ sperm) $\times$ ㅇ (DBA $\times$ C57BL/6 oocyte), where the ZFLacZ transgenic mice were originally generated from a SJL $\times$ C57BL/6 background. A total of five ICSI-derived mice (three males and two females) that expressed the $\beta$-galactosidase transgene were used in the analysis. To ensure that the reference DNA encompassed all the mouse genetic backgrounds, three groups of DNA were collected for CGH as 'pooled reference DNA'. Specifically, DNA, in equal amounts, from adult mice of C57BL/6, SJL and DBA strains were pooled as the 'pooled reference DNA'. DNA from adult, wild-type ZFLacZ progeny was collect as 'control wild-type DNA'; DNA from ZFLacZ progeny derived from cryopreserved testis cells via ICSI was collected as 'cryopreserved ICSI-derived DNA'. An appropriate amount of DNA was amplified 

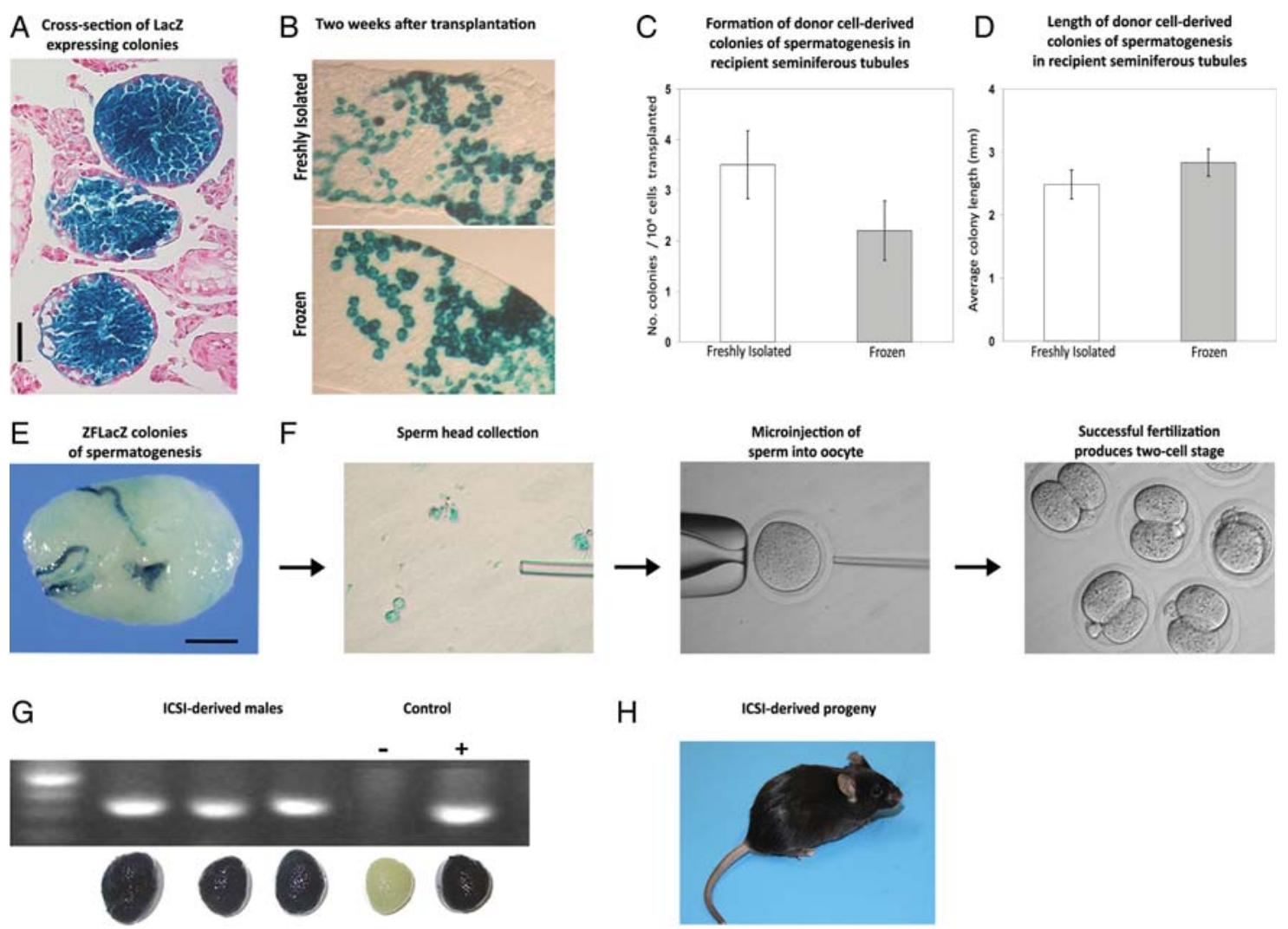

Figure I Cryopreserved mouse testis cells re-establish spermatogenesis in recipient testes and produce viable progeny. (A) LacZ expression in cryopreserved ( 14 years) ZFLacZ-derived germ cells (3 months after transplantation; Scale bar $=50 \mu \mathrm{m})$. (B) Cell-cell associations $(2$ weeks after transplantation) of testis cells derived from freshly isolated or cryopreserved ( $\sim 2$ years) ROSA mouse testes cells. (C) Donor-colonies produced in recipient testis 2 months after transplantation with freshly isolated $\left(3.5 \pm 0.67\right.$ colonies $/ 10^{4}$ cells transplanted) or cryopreserved $(2.2 \pm$ 0.58 colonies $/ 10^{4}$ cells transplanted) ROSA testis cells $(P=0.19)$. (D) Donor-colony length in recipient testes derived from freshly isolated or cryopreserved $(\sim 12$ years) ROSA testis cells $(P=0.65)$. Values are mean \pm SEM for freshly isolated $(n=6$ testes) and cryopreserved $(n=5$ testes $)$ testis cell transplanted. (E) Cryopreserved ( $\sim 4$ years) ZFLacZ colonies of spermatogenesis in recipient testes. (F) Sperm collected from ZFLacZ donorderived colonies were microinjected into oocytes, and fertilized 2-cell zygotes transplanted into surrogate female mice. (G) PCR amplification of LacZ transgene in ICSI-derived males ( $F_{0}$ progeny), along with corresponding $X$-gal staining of testes. ZFLacZ and SJL $\times C 57 B L / 6$ mice provided positive and negative controls, respectively. $(\mathbf{H})$ Image of representative LacZ expressing ICSI-derived $\mathrm{F}_{0}$ mouse.

according to the Agilent array $\mathrm{CGH}$ protocols prior to final labeling, microarray processing and feature extraction. $4 \times 180 \mathrm{~K}$ SurePrint $\mathrm{G} 3$ $\mathrm{CGH}$ Microarray Kits (Agilent Technologies, Wilmington, DE, USA, Cat\# G4I25A), were applied.

Agilent feature extraction files were imported into Partek Genomics Suite v6.5. Signals were processed from extracted green (Cy3) and red (Cy5) for each position on each array. 'Loess' normalization per arrayposition was applied, which resulted in normalized intensities for each experimental sample versus the 'pooled reference DNA' (Cy3 labeled). Inter-sample variation was visualized using principal component analysis $\geq$ observed gender difference as the only defined attribute that separated the samples. Grossly, 'cryopreserved ICSI-derived progeny' versus 'control wild-type progeny' did not separate samples, and no gross differences were observed for all chromosomes from plotted averages of probe intensities for 'cryopreserved ICSI-derived progeny' versus 'control wildtype progeny' (smoothed over nine probes). Two-way analysis of variance (ANOVA) (factors were 'cryopreserved ICSI-derived progeny' versus 'control wild-type progeny', and sex) was applied for all probes and generated a $t$-statistic for the pairwise-contrast between 'cryopreserved ICSI-derived progeny' versus 'control wild-type progeny'. For detection of significant regions differentiating 'cryopreserved' versus 'control', no regions were found to have detectable difference at default parameters $(P \leq 0.0$ I, fragment length 300 , min 10 probes, $10 \%$ high and low excluded).

\section{DNA methylation analyses}

A total of I $\mu g$ of DNA was bisulfite-treated using the EpiTect Bisulfite Kit (Qiagen) following the manufacturer's protocol. The LUminometric Methylation Assay was performed and analyzed as previously described using $500 \mathrm{ng}$ of genomic DNA and performed in quadruplicate (Pilsner et al., 2010). Pyrosequencing for methylation analysis of the differentially methylated regions (DMRs) of HI9 and Snrpn was performed using $50 \mathrm{ng}$ of bisulfite-treated DNA for PCR reactions. The HI9 primer sequences were as follows: forward primer 5'-GGGTAGGATATAT GTATTTTTTAGGTTG-3', biotinylated reverse primer 5'-CTCATAA AACCCATAACTATAAAATCAT-3'. The Snrpn primer sequences were as follows: forward primer 5'-GGTAGTTGTTTTTTGGTAGGATAT-3', biotinylated reverse primer 5'-ACTAAAATCCACAAACCCAACTAA CCT-3'. The PyroMark PCR Kit (Qiagen) was used following the 
manufacturer's protocol in a $25 \mu \mathrm{l}$ reaction. PCR conditions were: $95^{\circ} \mathrm{C}$ for $15 \mathrm{~min}$ followed by 45 cycles of $95^{\circ} \mathrm{C}$ for $15 \mathrm{~s}, 55^{\circ} \mathrm{C}$ for $30 \mathrm{~s}$ and $72^{\circ} \mathrm{C}$ for $15 \mathrm{~s}$. Each sequencing assay was carried using $10 \mu \mathrm{l}$ of the biotinylated PCR product with either the HI9 sequencing primer 5'-TGTAAAGATTAGGGTTGT-3' or Snrpn sequencing primer 5'-AAAAATGTGAGTATGTGTAGTTA-3'. Pyrosequencing was performed using PyroMark Q96MD (Qiagen) system following the manufacturer's protocol and the PyroMark Gold 96 Reagents Kit (Qiagen). Methylation was analyzed using Qiagen's Pyro Q-CpG software. All assays analyzing DNA methylation at imprinted genes were performed in duplicate.

\section{Cryopreservation studies}

We used testis cells from 6- to I4-day-old ROSA mouse pups and examined cryoprotectants previously reported to aid post-thaw viability. We initially tested the effect that the cryoprotectants DMSO and glycerol have on cell viability. To mSFM medium, which contained $0.2 \%$ bovine serum albumin (BSA; MP Biomedical, Solon, OH, Cat\# 194774, Lot\# RI455I), GDNF, GFR $\alpha$ I and bFGF, either DMSO (I0\% final concentration) or glycerol (I.4 M final concentration) was added. In addition, FBS ( $20 \%$ final concentration) was added to one-half of the tubes containing DMSO or glycerol. Cells were frozen at an uncontrolled or at two different controlled rates (i.e. Protocols I and 2), as previously reported (Kvist et al., 2006; Keros et al., 2007). The controlled rate of freezing was obtained using the BioCool II controlled rate freezer (FTS systems Inc., Warminster, PA, USA). In Protocol I (Keros et al., 2007), the rate of cooling was $1{ }^{\circ} \mathrm{C} \mathrm{min}^{-1}$ with a $5 \mathrm{~min}$ hold at $0^{\circ} \mathrm{C}$, followed by cooling at a rate of $0.5^{\circ} \mathrm{C} \mathrm{min}^{-1}$ to $-8^{\circ} \mathrm{C}$ and held for $10 \mathrm{~min}$, before being cooled to $-40^{\circ} \mathrm{C}$ at a rate of $0.5^{\circ} \mathrm{C} \mathrm{min}^{-1}$. The vials were held for $10 \mathrm{~min}$ at $-40^{\circ} \mathrm{C}$ following which cell freezing continued to $-70^{\circ} \mathrm{C}$ at a rate of $7^{\circ} \mathrm{C} \mathrm{min}^{-1}$ (Keros et al., 2007). Protocol 2 was adapted from Kvist et al. (2006), with some modifications. In brief, freezing of testes cells was initiated at a rate of $2^{\circ} \mathrm{C} \mathrm{min}-1$ to $-9^{\circ} \mathrm{C}$, followed by a $5 \mathrm{~min}$ hold time. Cells were frozen to $-40^{\circ} \mathrm{C}$ at a rate of $0.3^{\circ} \mathrm{C} \mathrm{min}^{-1}$, following which cells were further frozen to $-70^{\circ} \mathrm{C}$ overnight. The uncontrolled rate of freezing was obtained by placing testis cells in a Nalgene Cryo Freezing container (Thermo Fisher Scientific Inc., Pittsburgh, PA, USA) in a $-70^{\circ} \mathrm{C}$ freezer overnight, which results in a freeze rate of $\sim 1{ }^{\circ} \mathrm{C} \min ^{-1}$, as described by manufacturer. In all cases, cells were subsequently stored for $48 \mathrm{~h}$ in liquid $\mathrm{N}_{2}\left(-196^{\circ} \mathrm{C}\right)$. Following thawing in a $34^{\circ} \mathrm{C}$ water bath, testis cells were washed several times with I $\times$ HBSS, and viability was determined by trypan blue dye exclusion. Sucrose ( $0.07 \mathrm{M}$ final concentration) and $\mathrm{Y}-27632$, a selective inhibitor of the Rho-associated protein kinase pl 60 ROK ( $10 \mu$ M final conc., Calbiochem, San Diego CA, USA), were also evaluated for their added ability to safeguard SSCs through the freezing process (Gauthaman et al., 20I0). In addition, the cryoprotectant activity of polyvinylpyrrolidone (I\% PVP; Sigma, cat\# P-0930) was assessed as a replacement for FBS (Kim et al., 2008). To investigate the effect that different freezing conditions have on SSC viability, thawed testis cells were transplanted into recipient testes as described above.

\section{Statistical analyses}

All data were processed using the Statistical Package for the Social Sciences, vI8.0 (SPSS Inc., Chicago, IL, USA), and are present as mean \pm SEM, except for the CGH array experiments. To compare the difference between groups, univariate ANOVA was conducted using a Tukey's honest significant difference post hoc analysis. A difference was considered significant when the $P$-value was $\leq 0.05$.

\section{Results}

Testis cells from mouse, rat, rabbit and baboon were stored at $-196^{\circ} \mathrm{C}$ between 1995 and 1998. Upon thawing, the viability of testis cells was low, with viability ranging from I.5 to 17\% (Table I). We attributed this low testis cell viability to a lack of robust freezing methods that had not yet been developed at the time of freezing. Nonetheless, viable testis cells could be enriched to greater than 93\% from these samples by centrifugation through Percoll (Table I). In these studies, we used two mouse models, ROSA and ZFLacZ, both expressing the lac $Z$ transgene (see 'Materials and Methods' section). Transplantation of donor-derived SSCs into recipient testes is the only method for unequivocally demonstrating SSC presence (Brinster and Avarbock, 1994), and to provide an assessment of the effect of cryopreservation on donor testis cell populations that would be comparable with cells derived from prepubertal human males, testis cells from ZFlacZ mouse pups (age 6-14 days), frozen for $\sim 14$ years, were thawed and transplanted into recipient testes of mice in which endogenous spermatogenesis had been destroyed (Table I). Three months after transplantation, Lac Z expression was determined by $X$-gal staining of tubules, and we observed that donorderived SSCs generated colonies of spermatogenesis (Fig. IA). To evaluate the dynamics of donor SSC colonization in recipient testes, previously frozen $(\sim 12$ years) testis cells from adult $(\sim 3$ months old) ROSA mice were transplanted into the testes of busulfan-treated recipient mice. Two weeks after transplantation, $X$-gal staining of recipient testes showed that cryopreserved ( $\sim 12$ years) ROSA mouse testis cells formed cell-cell associations in transplanted recipients comparable with recipients transplanted with freshly isolated ROSA mouse testis cells (Fig. IB). Two months after transplantation, the

\begin{tabular}{|c|c|c|c|}
\hline $\begin{array}{l}F_{0} \\
\text { mouse \# }\end{array}$ & $\begin{array}{l}\text { ICSI or natural } \\
\text { mating }\end{array}$ & $\begin{array}{l}F_{0} \\
\text { Sex }\end{array}$ & Offspring $^{a}$ \\
\hline I & ICSI & $0^{7}$ & 9 pups in one litter $\left(5 q, 2 \sigma^{7}\right)$ \\
\hline 2 & ICSI & $\sigma^{7}$ & II pups in one litter $\left(7 q, 4 \sigma^{7}\right)$ \\
\hline 3 & ICSI & $\sigma^{7}$ & 9 pups in one litter $\left(69,2 \sigma^{7}\right)$ \\
\hline 4 & ICSI & q & $\begin{array}{l}23 \text { pups in two litters } \\
\left(119,120^{7}\right)\end{array}$ \\
\hline 5 & ICSI & q & I 8 pups in two litters $\left(79,110^{7}\right)$ \\
\hline 6 & Natural mating & $0^{7}$ & 7 pups in one litter $\left(29,5 \sigma^{7}\right)$ \\
\hline 7 & Natural mating & $0^{x}$ & 26 pups in two litter $\left(129,140^{\prime}\right)$ \\
\hline
\end{tabular}

The testes of recipient mice (\#A6090 and A609I) were transplanted with cryopreserved ( $\sim 4$ year) ZFLacZ donor testis cells. Blue-stained, LacZ positive testis cells from both mice were collected and pooled for generation of ICSI-derived progeny $\left(F_{0}\right.$ mouse ID\# I-5). ICSI-derived zygotes were transferred into two pseudo-pregnant ICR Swiss females to produce progeny; the three male $F_{0}$ progeny were derived from one female $\left(F_{0}\right.$ mouse ID \# I-3), and the two female $F_{0}$ progeny were from the second female ( $F_{0}$ mouse ID \# 4, 5). A recipient male (\#A6026) transplanted with cryopreserved ZFLacZ donor testis cells was housed with females and produced two $F_{0}$ progeny through natural mating ( $F_{0}$ mouse ID \# 6 and 7$)$. ${ }^{\text {a}} \mathrm{Females}$ often lose one or two pups in their first litter and in cases where total litter size does not correspond to the individual numbers of $q$ and $\sigma^{x}$ progeny per litter; it is because sex was not determined until weaning ( $\sim 3$ weeks). 
number of colonies of spermatogenesis produced in recipient testes transplanted with cryopreserved $(\sim 12$ years) or freshly isolated ROSA testis cells was $2.2 \pm 0.58$ colonies $/ 10^{4}$ cells transplanted and $3.5 \pm 0.67$ colonies $/ 10^{4}$ cells transplanted, respectively (Fig. IC, mean \pm SEM, $P=0.19)$. Moreover, the length of colonies generated from transplanted SSCs represents a critical assessment of SSC functional ability (Ryu et al., 2006), and no significant difference was observed in the length of spermatogenic colonies in recipient seminiferous tubules transplanted with either cryopreserved $(2.83 \pm$ $0.22 \mathrm{~mm})$ or freshly isolated $(2.48 \pm 0.23 \mathrm{~mm})$ ROSA mouse testis cells (Fig. ID; $P=0.65$ ). These findings indicate that long-term cryopreserved SSCs are able to re-establish normal spermatogenic colonies that are comparable with those from freshly isolated SSCs.

To demonstrate unequivocally that functional sperm are produced from cryopreserved ( $\sim 4$ years) mouse testis cells, colonies of spermatogenesis derived from the transplantation of previously frozen ZFlacZ donor testis cells (Fig. IE) were isolated, digested and sperm heads collected for ICSI into oocytes (Fig. IF). After $24 \mathrm{~h}$ incubation, 2-cell zygotes developed, which were transferred into surrogate females. The efficiency of generating 2-cell zygotes using sperm derived from freshly isolated testes in two control experiments was $21 / 40$ and $38 / 44$ (2-cell zygotes/total eggs injected). In three
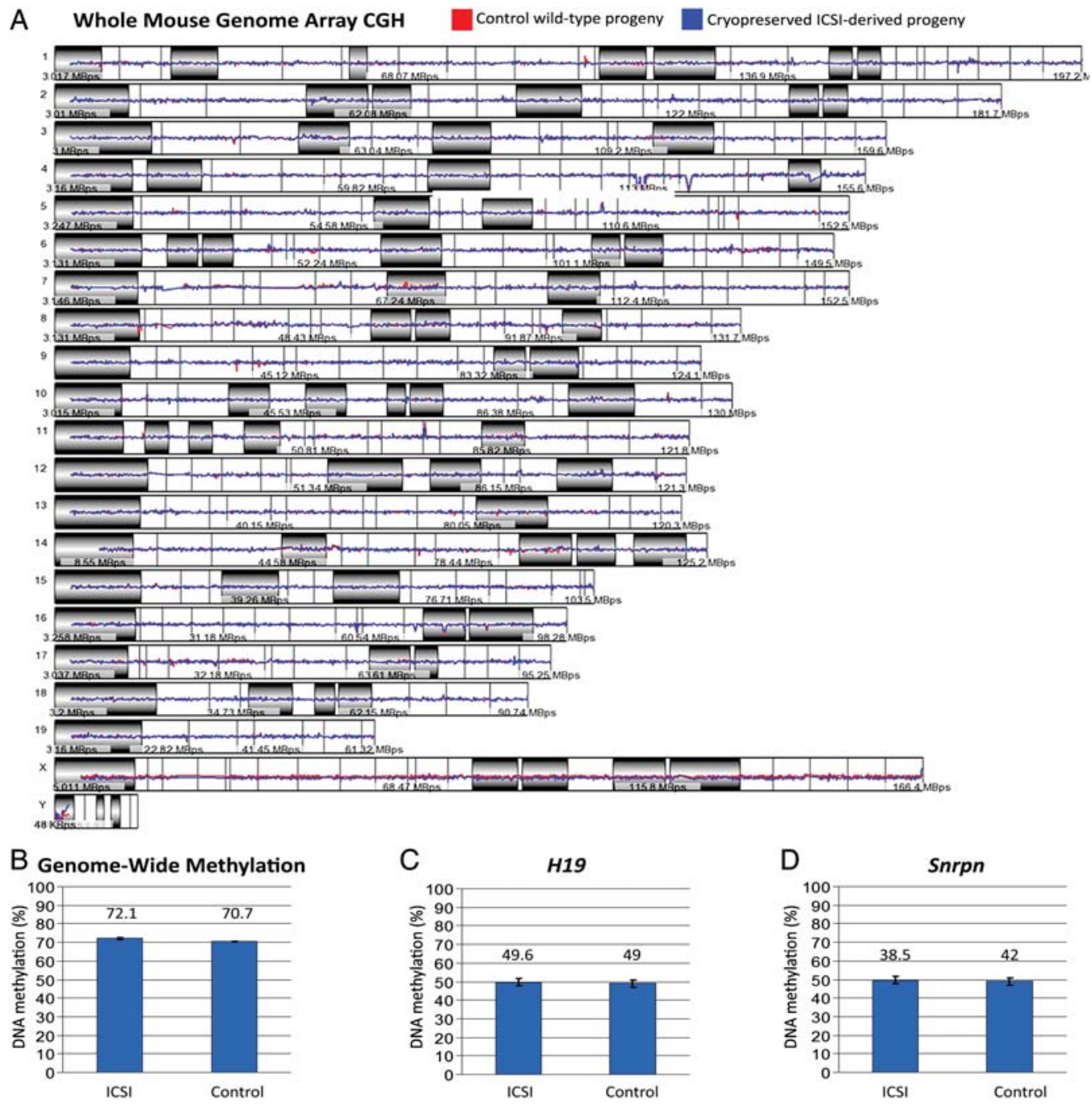

Figure 2 Analyses of $\mathrm{F}_{0}$ progeny generated by ICSI revealed no significant genetic or epigenetic alterations. (A) To measure changes in DNA copy number between $\mathrm{F}_{0}$ progeny generated by ICSI and control wild-type progeny obtained through natural mating we used array-based CGH array analysis. Using the statistical parameters defined in the Materials and Methods, no significant chromosomal deletions or duplications were observed between these two groups. (B) To further elucidate possible alterations in the genome of $F_{0}$ progeny generated by ICSI, we evaluated changes in whole genome DNA methylation using the luminometric methylation assay. The methylation percentages of ICSI-generated progeny $(72.1 \pm 0.44 \%)$ were not significantly different from control wild-type mice obtained through natural mating $(70.7 \pm 0.14 \%)$. Pyrosequencing of HI9 (C) and Snrpn (D) differentially methylated regions, comparing DNA methylation percentages between ICSI-derived progeny (49.6 \pm 1.86 and $38.5 \pm 1.96 \%$, respectively) and control wild-type mice obtained through natural mating (49 \pm 1.90 and $42 \pm 1.12 \%$, respectively) also did not yield any significant difference between groups. Values are mean \pm SEM. 


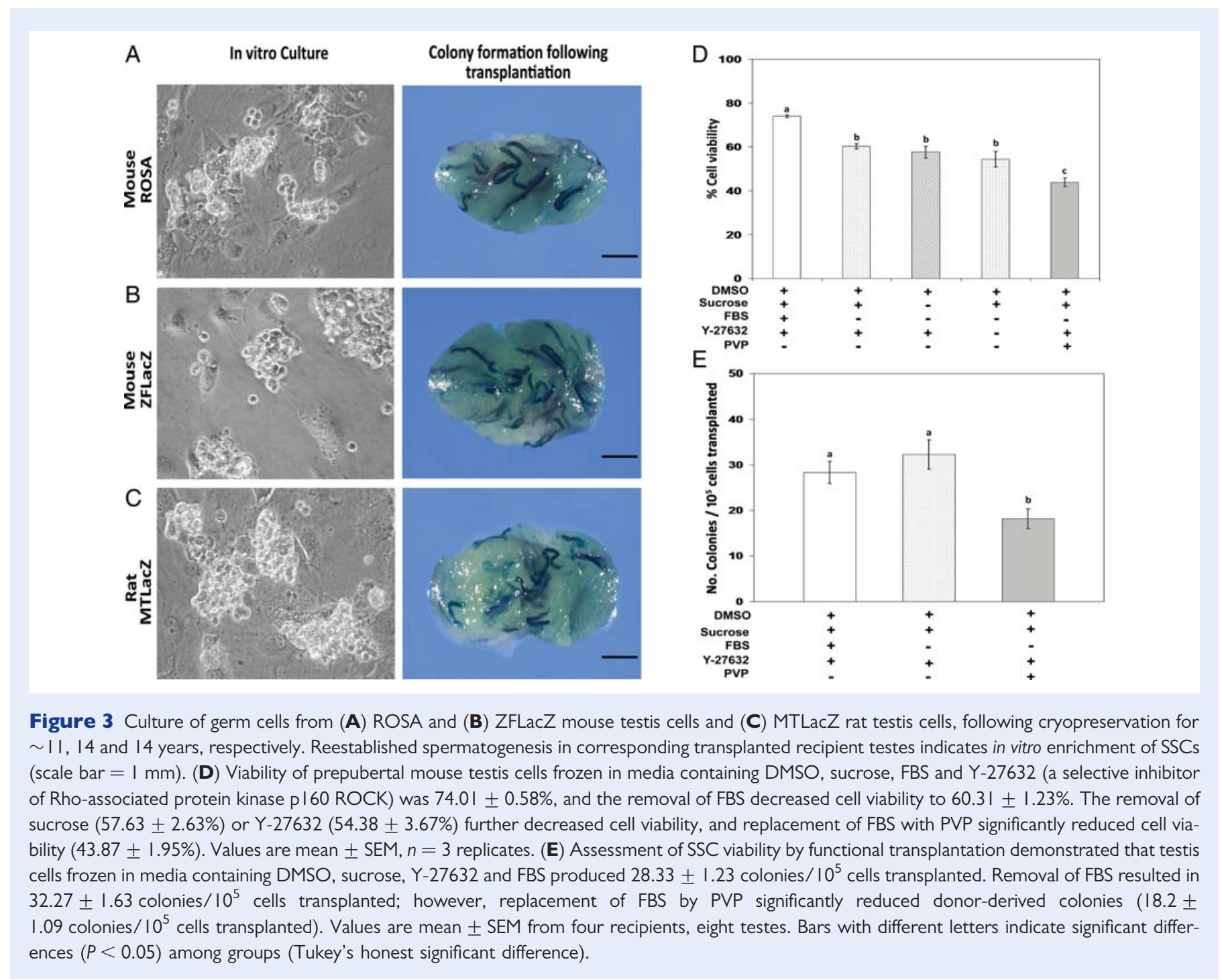

experimental injection experiments, the development of 2-cell zygotes using sperm derived from recipient testes transplanted with cryopreserved ( $\sim 14$ years) testis cells was $27 / 38,24 / 7$ । and $27 / 76$, respectively (2-cell zygotes/total eggs injected). The difference between the two experimental groups was not significant $(P=0.319)$. Importantly, sperm derived from the transplantation of previously frozen ZFlacZ donor testis cells produced a total of five pups (three males and two females) that carried the lac $Z$ transgene, which was present in donor testis cells (Fig. IG). All of the mice appeared normal $($ Fig. $\mathrm{IH})$. Additionally, two males were produced through natural mating of a recipient male transplanted with cryopreserved testis cells. Importantly, these $F_{0}$ males and females were fertile and produced fertile $F_{\text {I }}$ generations that appeared normal (Table II).

ART and germ cell cryopreservation raise concerns that deleterious genetic and epigenetic changes may be introduced into offspring (Alukal et al., 2008). Therefore, we screened the genomes of $F_{0}$ progeny (three males and two females) generated by ICSI that expressed the LacZ transgene using $\mathrm{CGH}$ array analysis and compared this with control wild-type mice obtained through natural mating (i.e. three males and two females). We observed no significant chromosomal deletions or duplications in the ICSI-derived mice compared with control wild-type mice (Fig. 2A). To assess possible epigenetic aberrations, we evaluated genome-wide DNA methylation in ICSI and control progeny and found no differences between the two groups (Fig. 2B). Additional pyrosequencing DMRs in the H/9 and Snrpn imprinted loci, which are associated with the Beckwith-Wiedemann syndrome and Prader-Willi syndrome (Bartolomei, 2009; Mak et al., 2010), respectively, also showed no significant difference between ICSI and control progeny (Fig. $2 \mathrm{C}$ and D). These results indicate that ICSI-derived mouse offspring generated from SSCs cryopreserved for $\sim 14$ years were not significantly different from natural offspring in these important genetic and epigenetic characteristics.

The efficient recovery of SSCs from prepubertal human testis biopsies for later transplantation and restoration of fertility is limited by the size of the initial tissue sample, as well as the small number of testis cells that possess stem cell potential ( $\sim$ I SSC is present in 3500 testis cells) capable of re-establishing spermatogenesis (Tegelenbosch and de Rooij, 1993; Wu et al., 2009). To overcome this obstacle, the SSC population contained within the testis biopsy will require in vitro expansion prior to transplantation in order to enable successful restoration of fertility. Since the in vitro conditions for rodent SSC culture are well defined (Kubota and Brinster, 2008), we evaluated the ability for 
mouse and rat testis cells cryopreserved for $\sim 12-14$ years to proliferate in culture. Cryopreserved ROSA ( $\sim 12$ years $)$ and ZFLacZ $(\sim 14$ years) mouse testis cells, as well as MTLacZ ( $\sim 14$ years) rat testis cells generated characteristic clumps of germ cell cultures containing SSCs. Cryopreserved ROSA ( $\sim 12$ years) and ZFLacZ ( $\sim 14$ years) mouse testis cells, and MTLacZ ( $\sim 14$ years) rat testis cells, following

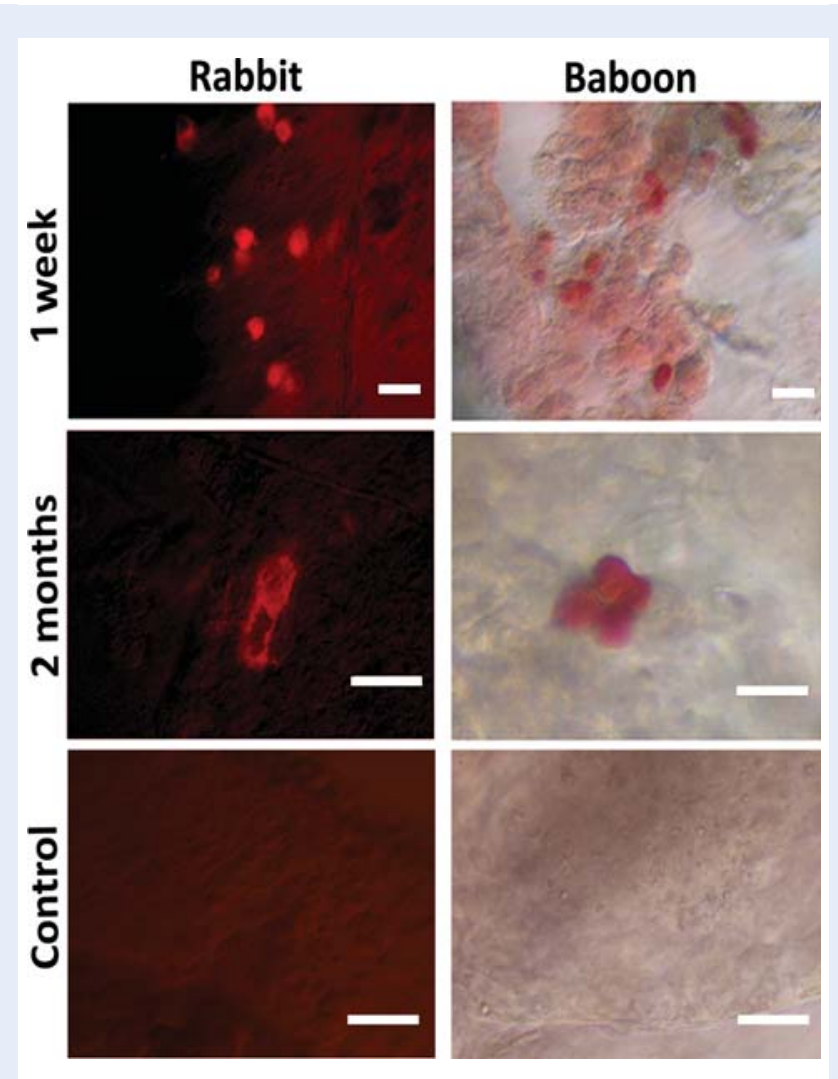

Figure 4 Rabbit and baboon testis cells cryopreserved for $\sim 12$ years colonized the seminiferous tubules of recipient mice. Rabbit testis cells were labeled with the fluorescent dye PKH26. Transplanted donor germ cells from rabbit were found on the basement membrane as single red cells I week after transplantation or as chains of 2-4 red cells 2 months after transplantation. Baboon testis cells were immunostained for the expression of UCHLI. In both cases, untransplanted, busulfan-treated testis provided negative control. Scale bar $=20 \mu \mathrm{m}$.
102, 98 and 147 days in culture, respectively, were transplanted into recipient testes and generated numerous colonies of spermatogenesis (Fig. 3A-C). In MTLacZ rats, the mouse MT promoter controls LacZ expression, which is first observed in spermatocytes (Clouthier et al., 1996). The above experiments demonstrate the presence of fully functional SSCs in testis samples from two species cryopreserved for $\sim 12$ to $\sim 14$ years. Although culture techniques were not available for rabbit and baboon germ cells, frozen testis cells from these species were transplanted into the testes of immunodeficient recipient mice, a technique previously described for assessing the presence of SSCs from species which are evolutionary distant from mice (Dobrinski et al., 2000, 2008; Nagano et al., 200I; Hermann et al., 2007). In this assay, SSCs, when present, are observed as transplanted cell pairs or small groups on the basement membrane of the seminiferous tubules in the recipient testes, and we observed these colonizing cells in seminiferous tubules of testes transplanted with cryopreserved ( $~ 12$ years) rabbit and baboon testis cells (Fig. 4). These studies strongly suggest the presence of SSCs in rabbit and baboon testis cells which have been frozen for long periods, but complete functional proof must await appropriate culture and transplantation methods to be developed for these species.

Because specialized procedures were not available at the time the testis cells were cryopreserved $\sim 12-14$ years ago, low cell viability was observed when the samples were thawed. Therefore, to optimize the freezing protocol for mammalian testis cells, the germ cells and importantly, SSCs, we used testis cells from prepubertal (6-14 days) ROSA mice and examined cryoprotectants previously reported to aid post-thaw viability (Izadyar et al., 2002; Gauthaman et al., 20I0). We found that an uncontrolled freezing rate was as effective as those of two published controlled freezing rates (Kvist et al., 2006; Keros et al., 2007), and that DMSO was better than glycerol as a cryoprotectant (Tables III and IV). We tested the cryoprotectant effects of sucrose and found that addition of sucrose to freezing media containing DMSO and FBS (20\%) had a minimal effect on cell viability (Table IV). However, the addition of a selective inhibitor of Rho-associated protein kinase pl60 ROCK (Y-27632) to a freezing medium in which sucrose was present, increased post-thaw viability (Table IV). This suggests a beneficial role of $Y-27632$ alone, but does not rule out the possibility that sucrose is necessary for the Y-27632 effect. Y-27632 increases the post-thaw survival of embryonic stem cells, reportedly through the inhibition of apoptosis (Gauthaman et al., 2010), and our results suggests a similar beneficial function for the addition of

Table III Comparison of DMSO and glycerol as a cryoprotectant for testis cells.

\begin{tabular}{|c|c|c|c|}
\hline \multirow[t]{2}{*}{ Cryoprotectants* } & \multicolumn{3}{|l|}{ Freezing protocol } \\
\hline & \% cell viability Protocol I & \% cell viability Protocol 2 & $\%$ cell viability uncontrolled rate \\
\hline 10\% DMSO & $53.06 \pm 6.97^{\mathrm{a}}$ & $71.04 \pm 1.45^{\mathrm{b}}$ & $71.81 \pm 1.56^{\mathrm{b}}$ \\
\hline $10 \% \mathrm{DMSO}+20 \% \mathrm{FBS}$ & $71.64 \pm 1.63^{b}$ & $73.03 \pm 1.87^{b}$ & $73.38 \pm 3.17^{b}$ \\
\hline I.4 M glycerol & $10.89 \pm 2.11^{c}$ & $10.90 \pm 1.15^{c}$ & $13.62 \pm\left. 3.4\right|^{c}$ \\
\hline I. 4 M glycerol $+20 \%$ FBS & $17.28 \pm 1.63^{c}$ & $15.49 \pm 1.82^{c}$ & $16.29 \pm 1.79^{c}$ \\
\hline
\end{tabular}

*All cryoprotectants were in mouse serum-free medium (mSFM) with added growth factors glial cell-derived neurotrophic factor (GDNF), GDNF family receptor $\alpha$ I (GFR $\alpha$ I) and basic fibroblast growth factor (bFGF). (mean \pm SEM, $n=3$ ).

Protocol I = Keros et al. (2007); Protocol 2 = Kvist et al. (2006). Values with different superscripts are significantly $(P<0.05)$ different $($ Tukey's honest significant difference). 


\section{Table IV Comparison of sucrose and Y-27632 as cryoprotectants for testis cells.}

\begin{tabular}{|c|c|c|}
\hline \multirow[t]{2}{*}{ Cryoprotectants* } & \multicolumn{2}{|c|}{ Freezing protocol } \\
\hline & $\begin{array}{l}\% \text { cell viability } \\
\text { Protocol } 2\end{array}$ & $\begin{array}{l}\% \text { cell viability } \\
\text { uncontrolled } \\
\text { rate }\end{array}$ \\
\hline $10 \%$ DMSO $+20 \%$ FBS & $63.38 \pm 1.85^{\mathrm{a}}$ & $68.80 \pm 1.31^{\mathrm{a}}$ \\
\hline $\begin{array}{l}10 \% \text { DMSO }+20 \% \\
\text { FBS }+0.07 M \text { sucrose }\end{array}$ & $69.25 \pm 0.37^{\mathrm{a}}$ & $67.59 \pm 1.26^{\mathrm{a}}$ \\
\hline $\begin{array}{l}10 \% \text { DMSO }+20 \% \\
\text { FBS }+0.07 M \text { sucrose }+10 \mu M \\
\text { inhibitor } Y-27632\end{array}$ & $76.89 \pm 1.37^{b}$ & $79.06 \pm 1.79^{b}$ \\
\hline \multicolumn{3}{|c|}{$\begin{array}{l}\text { *All cryoprotectants were in mSFM with added growth factors (GDNF, GFR } \alpha \text { I and } \\
\text { bFGF) (mean } \pm \text { SEM, } n=3 \text { ). } \\
\text { Protocol } 2=\text { Kvist et al. (2006). Different superscripts indicate significant }(P<0.05 \text { ) } \\
\text { differences among groups (Tukey's honest significant difference). } \\
\text { Y-27632: a selective inhibitor of Rho-associated protein kinase p } 160 \text { ROCK. }\end{array}$} \\
\hline
\end{tabular}

Y-27632 to the freezing medium although the mode of action requires additional experimentation.

The original freezing medium contained a small amount of BSA $(0.12 \%)$ from the mSFM used for SSC maintenance and culture and a significant amount of FBS (20\%), which would be an undesirable component of medium used for cells to be reintroduced into humans. Therefore, we tested the effect of PVP as a possible replacement for FBS in the freeze medium on testis cell viability and found that removal of FBS results in a small (13.7\%) but significant reduction in testis cell viability. The removal of sucrose or Y-27632 had no additional effect in the absence of FBS. However, addition of $1 \%$ PVP resulted in a large (30.2\%), significant reduction in testis cell viability in the absence of FBS (Fig. 3D).

The generation of donor-derived spermatogenesis following transplantation of cryopreserved testis cells provides a critically important parameter to measure SSC survival, which may be different from total testis cell viability, and is the critical end-point. We tested three of the original five freezing media in Fig. 3D to specifically examine the influence of FBS and PVP on SSCs. The absence of FBS had no effect on the number of SSCs present but the presence of PVP significantly decreased colony formation, a definitive measure of SSC number (Fig. 3E). Therefore, while FBS in the freezing medium significantly decreased the viability of mouse testis cells (Fig. 3D), the viability of mouse SSCs was not affected by the absence of FBS (Fig. 3E). A freeze medium based on mSFM with BSA (0.12\%), 10\% DMSO, sucrose and $\mathrm{Y}-27632$ resulted in $60.3 \%$ viability of cryopreserved prepubertal mouse testis cells and generation of $32.27 \pm$ 1.63 colonies per $10^{5}$ cryopreserved testis cells transplanted (Fig. 3D and E). These parameters may serve as a useful framework for clinical applications involving freezing of prepubertal human testis cells.

\section{Discussion}

Gonadal damage is a relatively common consequence of treatments used to cure pediatric cancer, and male germ cells are particularly susceptible to injury by cytotoxic drugs and radiation therapy (Ginsberg et al., 2010). As treatment regimens for pediatric malignancies have improved, survivors are entering their reproductive years, and maintenance of fertility is extremely important with regard to long-term quality of life (Hewitt et al., 2003). Cryopreservation of testicular tissue, prior to the start of cancer therapy, provides a novel approach to preserve a patient's future reproductive potential (Goossens and Tournaye, 2007; Jahnukainen et al., 2007, 20I la,b). Unfortunately, this approach is currently a limited option for many parents and patients because many practical and ethical concerns need to be addressed. Since 10 years or more may elapse before a cryopreserved testicular tissue biopsy is recovered to reestablish fertility, it is essential to understand the impact that long-term cryopreservation may have on the viability and function of SSCs. Our previous studies have shown that following cryopreservation of mouse testis cells for several months the SSCs within the cell population can restore spermatogenesis in the testes of recipient mice (Avarbock et al., 1996). However, longer periods, comparable to those that would be necessary in the human clinical setting, have not been evaluated for the ability of the frozen stem cells to reestablish spermatogenesis and produce viable, fertile progeny. Moreover, possible genetic and epigenetic abnormalities that may occur from cryopreservation have not been evaluated. Our current findings demonstrate that following long-term ( 12-14 years) cryopreservation the SSC population of mouse, rat, rabbit and baboon remains viable. Cryopreserved mouse and rat testis cells reestablished spermatogenesis in recipient testes, and recipients of cryopreserved mouse testis cells could generate normal appearing, fertile progeny without apparent genetic or epigenetic errors. These findings provide experimental evidence for physicians to use in counseling parents and young patients regarding the usefulness of a testis biopsy to preserve the potential for future fertility.

Since long-term cryopreservation of testis cells and SSCs is a feasible clinical option, it is critical to improve the associated methods. Whereas previous studies have attempted to define optimal methods for freezing spermatids and spermatozoa (Ogonuki et al., 2006), little is known about conditions that maximally preserve undifferentiated germ cells containing the SSC population. In particular, the use of animal sera, such as FBS, for cryopreserving human testis cells may restrict clinical application because of the possible transmission of viral and prion-related vectors (Unger et al., 2008). In this study, we demonstrate that a simple medium containing 10\% DMSO, sucrose and Y-27632A maintains SSC viability and function, and that withdrawal of FBS from the freezing medium does not significantly impact postthaw viability and function of cryopreserved SSCs under the conditions developed.

These findings have important clinical implications as treatment regimens for pediatric cancers continue to improve, and the data presented here strongly support the feasibility of prolonged SSC cryopreservation and subsequent restoration of fertility for prepubertal boys undergoing cancer therapy.

\section{Acknowledgements}

We thank Dr J.R. McCarrey for providing baboon testis samples; C. Freeman and R. Naroznowski for assistance with animal maintenance, and James R Hayden for photography. CGH array data has been deposited in the National Center for Biotechnology Information 
Gene Expression Omnibus (GEO) database (www.ncbi.nlm.nih .gov_geo accession no. GSE35056).

\section{Authors' roles}

X.W, S.M.G., and R.L.B. designed experiments, X.W. and M.R.A. performed experiments. X.W., S.M.G. and R.L.B. analyzed data and wrote the paper; L.K.A. and M.S.B. performed and analyzed DNA methylation studies. J.W.T. analyzed CGH array profile.

\section{Funding}

This study was supported by National Institute of Health grants T32GM008216 (L.K.A.), GM 51279 (M.S.B.), HD 052728 (R.L.B.) and the Robert J. Kleberg, Jr. and Helen C. Kleberg Foundation (R.L.B.).

\section{Conflict of interest}

None declared.

\section{References}

Alukal JP, Lipshultz LI. Safety of assisted reproduction, assessed by risk of abnormalities in children born after use of in vitro fertilization techniques. Nat Clin Pract Urol 2008;5:40-150.

Avarbock MR, Brinster CJ, Brinster RL. Reconstitution of spermatogenesis from frozen spermatogonial stem cells. Nat Med 1996;2:693-696.

Bartolomei MS. Genomic imprinting: employing and avoiding epigenetic processes. Genes Dev 2009;23:2124-2133.

Brinster RL. Studies on the development of mouse embryos in vitro. II. The effect of energy source. J Exp Zool 1965;1 158:9-68.

Brinster RL. Male germline stem cells: from mice to men. Science 2007 3 16:404-405.

Brinster RL, Avarbock MR. Germline transmission of donor haplotype following spermatogonial transplantation. Proc Natl Acad Sci USA 1994; 91:1303-1|307.

Brinster RL, Zimmermann JW. Spermatogenesis following male germ-cell transplantation. Proc Natl Acad Sci USA 1994;9 I: I 298- I I302.

Clouthier DE, Avarbock MR, Maika SD, Hammer RE, Brinster RL. Rat spermatogenesis in mouse testis. Nature 1996;381:418-421.

Dobrinski I. Male germ cell transplantation. Reprod Domest Anim 2008; 43(Suppl 2):288-294.

Dobrinski I, Avarbock MR, Brinster RL. Transplantation of germ cells from rabbits and dogs into mouse testes. Biol Reprod 1999;6 I:|331-1339.

Dobrinski I, Avarbock MR, Brinster RL. Germ cell transplantation from large domestic animals into mouse testes. Mol Reprod Dev 2000; 57:270-279.

Gauthaman K, Fong CY, Subramanian A, Biswas A, Bongso A. ROCK inhibitor $Y$-27632 increases thaw-survival rates and preserves stemness and differentiation potential of human Wharton's jelly stem cells after cryopreservation. Stem Cell Rev 20 10;6:65-676.

Geens M, Goossens E, De Block G, Ning L, Van Saen D, Tournaye H. Autologous spermatogonial stem cell transplantation in man: current obstacles for a future clinical application. Hum Reprod Update 2008; I4:2I-130.

Ginsberg JP, Carlson CA, Lin K, Hobbie W, Wigo E, Wu X, Brinster RL, Kolon TF. An experimental protocol for fertility preservation in prepubertal boys recently diagnosed with cancer: a report of acceptability and safety. Hum Reprod 2010;25:37-4I.
Goossens $\mathrm{E}$, Tournaye $\mathrm{H}$. Is there a clinical future for spermatogonial stem cells? Curr Stem Cell Res Ther 2007;2: 189- 195.

Hermann BP, Sukhwani M, Lin CC, Sheng Y, Tomko J, Rodriguez M, Shuttleworth J), McFarland D, Hobbs RM, Pandolfi PP et al. Characterization, cryopreservation, and ablation of spermatogonial stem cells in adult rhesus macaques. Stem Cells 2007;25:2330-2338.

Hewitt M, Weiner S, Simone J. Childhood Cancer Survivorship: Improving Care and Quality of Life. Washington, DC: National Academies Press, 2003.

Izadyar F, Matthijs-Rijsenbilt JJ, den Ouden K, Creemers LB, Woelders H, de Rooij DG. Development of a cryopreservation protocol for type $A$ spermatogonia. J Androl 2002;23:537-545.

Jahnukainen K, Ehmcke J, Söder O, Schlatt S. Clinical potential and putative risks of fertility preservation in children utilizing gonadal tissue or germline stem cells. Pediatr Res 2006;59:40R-47R.

Jahnukainen K, Ehmcke J, Hergenrother SD, Schlatt S. Effect of cold storage and cryopreservation of immature non-human primate testicular tissue on spermatogonial stem cell potential in xenografts. Hum Reprod 2007;22:1060-1067.

Jahnukainen K, Ehmcke J, Hou M, Schlatt S. Testicular function and fertility preservation in male cancer patients. Best Pract Res Clin Endocrinol Metab 20I Ia;25:287-302.

Jahnukainen K, Ehmcke J, Quader MA, Saiful Huq M, Epperly MW, Hergenrother S, Nurmio M, Schlatt S. Testicular recovery after irradiation differs in prepubertal and pubertal non-human primates, and can be enhanced by autologous germ cell transplantation. Hum Reprod 201 Ib;26:1945-1954.

Kanatsu-Shinohara M, Ogonuki N, Inoue K, Ogura A, Toyokuni S, Shinohara T. Restoration of fertility in infertile mice by transplantation of cryopreserved male germline stem cells. Hum Reprod 2003; I 8:2660-2667.

Keros V, Hultenby K, Borgström B, Fridström M, Jahnukainen K, Hovatta O. Methods of cryopreservation of testicular tissue with viable spermatogonia in pre-pubertal boys undergoing gonadotoxic cancer treatment. Hum Reprod 2007;22: I384-1395.

Kim CG, Yong H, Lee G, ChoJ. Effect of the polyvinylpyrrolidone concentration of cryoprotectant on mouse embryo development and production of pups: $7.5 \%$ of PVP is beneficial for in vitro and in vivo development of frozen-thawed mouse embryos. J Reprod Dev 2008;54:250-253.

Kimura Y, Yanagimachi R. Intracytoplasmic sperm injection in the mouse. Biol Reprod 1995;52:709-720.

Kubota H, Brinster RL. Culture of rodent spermatogonial stem cells, male germline stem cells of the postnatal animal. Methods Cell Biol 2008;86:59-84.

Kvist K, Thorup J, Byskov AG, Høyer PE, Møllgård K, Yding Andersen C. Cryopreservation of intact testicular tissue from boys with cryptorchidism. Hum Reprod 2006;2 1:484-49I.

Luo J, Megee S, Dobrinski I. Asymmetric distribution of UCH-LI in spermatogonia is associated with maintenance and differentiation of spermatogonial stem cells. J Cell Physiol 2009;220:460-468.

Mak W, Weaver JR, Bartolomei MS. Is ART changing the epigenetic landscape of imprinting? Anim Reprod 2010;7:168-176.

Mitchell RT, Saunders PT, Sharpe RM, Kelnar CJ, Wallace WH. Male fertility and strategies for fertility preservation following childhood cancer treatment. Endocr Dev 2009;15:101-134.

Nagano M, Avarbock MR, Brinster RL. Pattern and kinetics of mouse donor spermatogonial stem cell colonization in recipient testes. Biol Reprod 1999;60:1429-1436.

Nagano M, McCarrey JR, Brinster RL. Primate spermatogonial stem cells colonize mouse testes. Biol Reprod 2001;64:1409-1416.

Oatley JM, Brinster RL. Spermatogonial stem cells. In: Klimanskaya I, Lanza R (eds) Methods Enzymology, Vol. 419. San Diego, CA: Academic Press, 2006, 259-282.

Ogonuki N, Mochida K, Miki H, Inoue K, Fray M, Iwaki T, Moriwaki K, Obata $\mathrm{Y}$, Morozumi K, Yanagimachi $\mathrm{R}$ et al. Spermatozoa and 
spermatids retrieved from frozen reproductive organs or frozen whole bodies of male mice can produce normal offspring. Proc Natl Acad Sci USA 2006; 103:13098-130103.

Pilsner RJ, Lazarus AL, Nam DH, Letcher RJ, Sonne C, Dietz R, Basu N. Mercury-associated DNA hypomethylation in polar bear brains via the LUminometric Methylation Assay: a sensitive method to study epigenetics in wildlife. Mol Ecol 2010;19:307-3/4.

Radford J. Is prevention of sterility possible in men? Ann Oncol 2000; I I(Suppl 3): I73- 174.

Ryu BY, Orwig KE, Oatley JM, Avarbock MR, Brinster RL. Effects of aging and niche microenvironment on spermatogonial stem cell self-renewal. Stem Cells 2006;24:1505-1511.

Sauvat F, Binart N, Poirot C, Sarnacki S. Preserving fertility in prepubertal children. Horm Res 2009;7I (Suppl I):82-86.

Schlatt S, Ehmcke J, Jahnukainen K. Testicular stem cells for fertility preservation: preclinical studies on male germ cell transplantation and testicular grafting. Pediatr Blood Cancer 2009;53:274-280.

Tegelenbosch RA, de Rooij DG. A quantitative study of spermatogonial multiplication and stem cell renewal in the $\mathrm{C} 3 \mathrm{H} / \mathrm{IOI} \mathrm{F}_{1}$ hybrid mouse. Mutat Res 1993;290:193-200.
Unger C, Skottman H, Blomberg P, Dilber MS, Hovatta O. Good manufacturing practice and clinical-grade human embryonic stem cell lines. Hum Mol Genet 2008; I7:R48-R53.

Wu X, Schmidt JA, Avarbock MR, Tobias JW, Carlson CA, Kolon TF, Ginsberg JP, Brinster RL. Prepubertal human spermatogonia and mouse gonocytes share conserved gene expression of germline stem cell regulatory molecules. Proc Natl Acad Sci USA 2009; 106:21672-21677.

Wyns C, Curaba M, Vanabelle B, Van Langendonckt A, Donnez J. Options for fertility preservation in prepubertal boys. Hum Reprod Update 2010; 16:312-328.

Wyns C, Curaba M, Petit S, Vanabelle B, Laurent P, Wese JF, Donnez J. Management of fertility preservation in prepubertal patients: 5 years' experience at the Catholic University of Louvain. Hum Reprod 20I I; 26:737-747.

Zambrowicz BP, Zimmermann JW, Harendza CJ, Simpson EM, Page DC, Brinster RL, Palmiter RD. Expression of a mouse Zfy-l/lacZ transgene in the somatic cells of the embryonic gonad and germ cells of the adult testis. Development 1994; I 20: I549- I559. 